\title{
A Comparison of Clinical Outcomes for Breast-conserving Treatment and Mastectomy for Early Breast Cancer
}

\author{
Jae Myoung Noh, M.D.*, Won Park, M.D.*, Seung Jae Huh, M.D.*, Doo Ho Choi, M.D.*, \\ Jung Hyun Yang, M.D. ${ }^{\dagger}$, Seok Jin Nam, M.D. ${ }^{\dagger}$, Jeong Han Kim, M.D. ${ }^{\dagger}$, \\ Young Hyuck Im, M.D. ${ }^{\dagger}$ and Jin Seok Ahn, M.D. ${ }^{\dagger}$ \\ Departments of *Radiation Oncology, ${ }^{\dagger}$ Surgery and ${ }^{\dagger}$ Hematology-oncology, \\ Sungkyunkwan University School of Medicine, Seoul, Korea
}

\begin{abstract}
Purpose: To compare the treatment outcomes and to analyze prognostic factors between the use of a breast-conserving treatment (BCT) and a mastectomy for early stage breast cancer.

Materials and Methods: We retrospectively reviewed 1,200 patients with pathological stage T1-2N0 breast cancer who received surgery between September 1994 and December 2002 at Samsung Medical Center. We compared the patient characteristics and treatment outcomes between the two treatment groups.

Results: Among the 1,174 eligible patients, 601 (51.2\%) patients received a BCT and the remaining 573 $(48.8 \%)$ patients received a mastectomy. The mastectomy group of patients had significantly more cases with a larger tumor size, multicentricity, extensive intraductal component, and estrogen- and progesterone-receptor negativity. The ten-year overall survival rates (OS) of the BCT and mastectomy groups were $91.96 \%$ and $91.01 \%$, respectively $(\mathrm{p}=0.1274)$. The ten-year disease-free survival rates (DFS) were $80.48 \%$ for the BCT group of patients and $84.95 \%$ for the mastectomy group of patients, respectively $(p=0.8795)$. Conclusion: Our study shows some differences in patient characteristics between the two treatment groups. However, these differences did not result in significant survival differences.
\end{abstract}

Key Words: Breast cancer, Breast-conserving surgery, Mastectomy

\section{Introduction}

Breast cancer is the most common malignancy in female patients in Korea. ${ }^{1,2)}$ The incidence has been rapidly increasing and reached 40.5 per 100,000 women in $2004{ }^{3)}$ For breast cancer treatment, about forty-two percent of patients receive breast-conserving surgery (BCS). This represents a two-fold increase since 1996. ${ }^{4}$

The surgical approach to the primary breast cancer involves excision of all invasive cancer with clear resection margins. There have been several surgical methods from radical mastectomy to conservation surgery such as wide local excision, segmentectomy or quadrantectomy. ${ }^{57)}$ But conser-

Submitted August 2, 2007, accepted January 17, 2008

Reprint requests to Won Park, Department of Radiation Oncology, Samsung Medical Center, Sungkyunkwan University School of Medicine, 50, IIwon-dong, Gangnam-gu, Seoul 135-710, Korea Tel: 02)3410-2616, Fax: 02)3410-2619

E-mail: wonro.park@samsung.com vation surgery only developed local recurrence from $24 \%$ to $40 \%{ }^{8 \sim 11)}$ After breast conserving surgery (BCS), postoperative irradiation reduced the local recurrence rate about $70 \%{ }^{10,11)}$ Several prospective randomized trials compared treatment outcomes between BCS followed by radiotherapy (BCT) and mastectomy in early stage breast cancer. The survival rates were similar, but local recurrence was more apparent in BCT group..$^{10,12 \sim 16)}$ Given these study results, BCT has become an accepted treatment for early breast cancer patients. ${ }^{17,18)}$ In this study, we retrospectively analyzed the treatment outcomes of pathologic stage T1-2N0 breast cancer patients between a mastectomy and BCT.

\section{Materials and Methods}

From September 1994 to December 2002, 1,200 patients were diagnosed with pathological stage T1-2N0 breast cancer at Samsung Medical Center in Korea. Among the patients, 21 patients who received neoadjuvant chemotherapy and 5 
patients who did not receive breast irradiation after BCS were excluded from the analysis. The remaining 1,174 patients were eligible for the retrospective review.

Patients ranged in age from 23 to 82 years with a median age of 46 years. Six hundred one patients $(51.2 \%)$ received BCS followed by breast irradiation, and the remaining 573 patients $(48.8 \%)$ received mastectomy. After BCS, whole breast irradiation with the tangential technique was administered with $45 \sim 50.4$ Gy with a daily fraction size of 1.8 2 Gy. Then, a local boost to the tumor bed was provided with 9 14 Gy in 549 patients (91.3\%). After a mastectomy, 13 patients received chest wall irradiation because of positive or close surgical margins. No patient received radiation of the supraclavicular fossa. Adjuvant chemotherapy was given to $356(59.2 \%)$ of the BCT group and 399 (69.6\%) of the mastectomy group. Most of the chemotherapeutic regimens included combinations of cyclophosphamide, methotrexate and fluorouracil $(99.2 \%$ for the BCT group and $97.2 \%$ for the mastectomy group). Adjuvant hormonal therapy was given to 322 patients $(53.6 \%)$ in the BCT group and 287 patients $(50.1 \%)$ in the mastectomy group, most used tamoxifen.

The median follow-up period of surviving patients was 60 months (range 3 136 months) and 65 months (range 2 131 months) for BCT group and mastectomy group, respectively. At the time of analysis, 491 patients $(81.7 \%)$ out of BCT group and 433 patients (75.6\%) out of mastectomy group were under regular follow-up. Fifty-nine patients $(9.8 \%)$ in BCT group and 73 patients (12.7\%) in mastectomy group were lost during follow-up under median follow-up time. We compared the patient characteristics between the treatment groups using the t-test and $\chi^{2}$-test. The Kaplan-Meier method was used to calculate overall survival and disease free survival. To compare treatment outcomes and analyze prognostic factors, we used the Log-Rank test and the Cox proportional hazard test. Statistical analysis was performed with the SAS $^{\circledR}$ system (SAS 9.0, SAS Institute Inc., Cary,

Table 1. Comparison of Patient Characteristics Enrolled 1,174 Patients according to Treatment Modality

\begin{tabular}{|c|c|c|c|c|}
\hline \multicolumn{2}{|c|}{ Characteristics } & $\mathrm{BCT}^{*}(\%) \quad(\mathrm{n}=601)$ & Mastectomy $(\%) \quad(n=573)$ & $\mathrm{p}$-value \\
\hline \multicolumn{2}{|c|}{ Age (years) } & 27 79 (median 45) & $23 \sim 82$ (median 45 ) & 0.0361 \\
\hline \multirow[t]{3}{*}{ Location } & Right & $271(45.1)$ & $273(47.6)$ & 0.0692 \\
\hline & Left & $325(54.1)$ & $300(52.4)$ & \\
\hline & Bilateral & $5(0.8)$ & 0 & \\
\hline \multirow[t]{2}{*}{$\mathrm{T}$ stage } & 1 & $460(76.5)$ & $286(49.9)$ & $<0.0001$ \\
\hline & 2 & $141(23.5)$ & $287(50.1)$ & \\
\hline \multirow[t]{2}{*}{ Menopause } & Yes & $212(35.2)$ & $213(37.2)$ & 0.4987 \\
\hline & No & $389(64.8)$ & $360(62.8)$ & \\
\hline \multirow[t]{2}{*}{ Multicentricity } & Yes & $26(4.3)$ & 68 (11.9) & $<0.0001$ \\
\hline & No & $575(95.7)$ & $505(88.1)$ & \\
\hline \multirow[t]{2}{*}{$\mathrm{LVI}^{\dagger}$} & Yes & $38(6.3)$ & $48(8.4)$ & 0.1769 \\
\hline & No & $563(93.7)$ & $525(91.6)$ & \\
\hline \multirow[t]{2}{*}{$\mathrm{EIC}^{\ddagger}$} & Yes & $128(21.5)$ & $171(30.2)$ & 0.0007 \\
\hline & No & $468(78.5)$ & $396(69.8)$ & \\
\hline \multirow[t]{2}{*}{$\mathrm{ER}^{\S}$} & Positive & $341(65.6)$ & $297(58.3)$ & 0.0169 \\
\hline & Negative & $179(34.4)$ & $212(41.7)$ & \\
\hline \multirow[t]{2}{*}{$\mathrm{PR}^{\|}$} & Positive & $267(51.5)$ & $224(44.4)$ & 0.0231 \\
\hline & Negative & $251(48.5)$ & $280(55.6)$ & \\
\hline \multirow[t]{3}{*}{ Nuclear grade } & Low & $70(13.9)$ & $62(12.1)$ & 0.6835 \\
\hline & Intermediate & $257(51.2)$ & $269(52.5)$ & \\
\hline & High & $175(34.9)$ & $181(35.4)$ & \\
\hline \multirow[t]{3}{*}{ Histologic grade } & Well & $74(17.0)$ & 57 (14.1) & 0.4249 \\
\hline & Moderate & $183(42.0)$ & $184(45.3)$ & \\
\hline & Poor & $179(41.0)$ & $165(40.6)$ & \\
\hline \multirow[t]{2}{*}{ Resection margin } & $\leq 2 \mathrm{~mm}$ & $62(10.3)$ & 67 (11.7) & 0.4509 \\
\hline & $>2 \mathrm{~mm}$ & $539(89.7)$ & $506(88.3)$ & \\
\hline
\end{tabular}

*breast-conserving treatment, ${ }^{\dagger}$ lymphovascular space invasion, ${ }^{\dagger}$ extensive intraductal component, ${ }^{\S}$ estrogen-receptor, "progesteron-receptor 


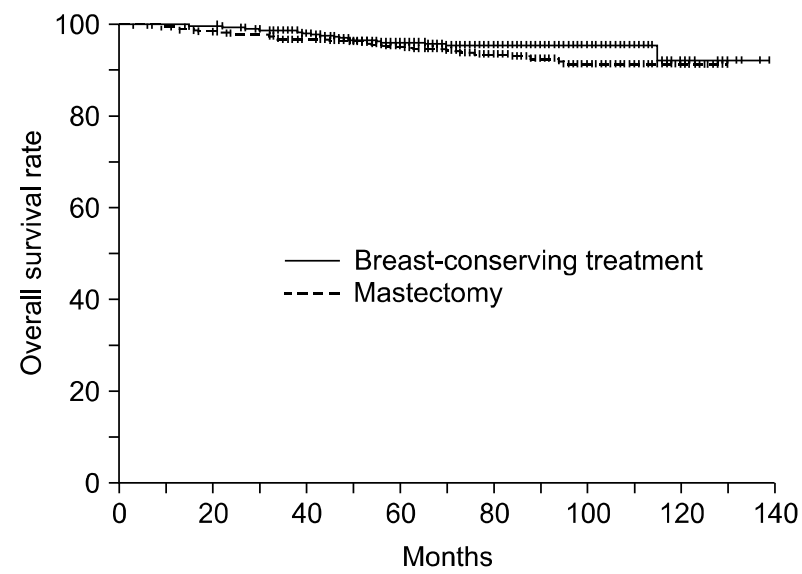

Fig. 1. Overall survival rate according to treatment modality. The ten-year overall survival rate was $91.96 \%$ and $91.01 \%$ for breast conserving treatment and mastectomy, respectively $(\mathrm{p}=0.1274)$.

NC., USA).

\section{Results}

Among the BCT group, 460 (76.5\%) patients had pathologic $\mathrm{T} 1$ stage and the remaining 141 (23.5\%) patients had pathologic T2 stage. Two hundred eighty-six (49.9\%) patients of the mastectomy group had pathologic T1 stage ( $\mathrm{p}$ $<0.0001)$. The mastectomy group had significantly more patients with multicentricity, estrogen- and progesteronereceptor negativity (Table 1 ).

During the follow-up period, twenty-three patients $(3.8 \%)$ in the BCT group and twelve patients $(2.1 \%)$ in the mastectomy group showed local recurrence $(\mathrm{p}=0.0810)$. Regional (ipsilateral axilla and supraclavicular) recurrence was detected in 21 patients $(3.7 \%)$ of the mastectomy group, which was significantly more frequent than 10 patients $(1.7 \%)$ of the BCT group ( $\mathrm{p}=0.0326)$. Fifty-eight patients $(9.7 \%)$ and seventy-one patients (12.4\%) in each group had distant recurrence $(p=0.1334)$. The sites of distant metastases were bone, lung, liver and brain in order of frequency with no difference noted between treatment modalities.

The ten-year overall survival rate (OS) and disease free survival rate (DFS) for all patients was $91.73 \%$ and $83.29 \%$. The ten-year OS in the BCT group was $91.96 \%$, which was not significantly different from that of the mastectomy group (91.01\%, p=0.1274, Fig. 1). There was also no significant

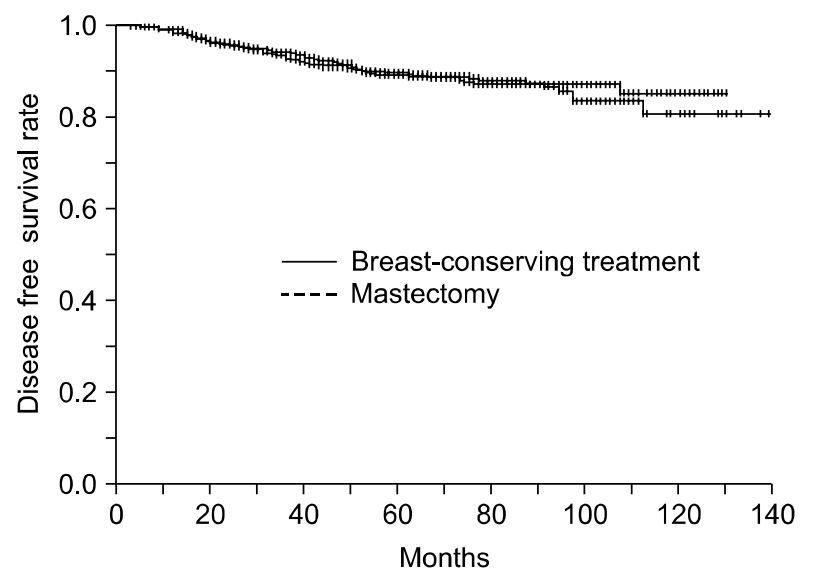

Fig. 2. Disease free survival rate according to treatment modality. The ten-year disease free survival rate was $80.48 \%$ and $84.95 \%$ in the breast conserving treatment and mastectomy, respectively $(\mathrm{p}=0.8795)$.

difference in the 10-year DFS between the two groups ( $80.48 \%$ and $84.95 \%, p=0.8795$, Fig. 2).

The multivariate analysis showed that T-stage significantly affected both OS and DFS ( $p=0.0213$ and 0.0164). Lymphovascular space invasion (LVI) and histologic grade affected DFS ( $p=0.0143$ and 0.0038 , Table 2). We analyzed the survival outcome according to treatment modalities in same T-stage, OS was not significantly affected by treatment modalities (Table 3). But DFS of BCT group was significantly inferior to that of mastectomy group in $\mathrm{T} 1$ patients $(\mathrm{p}=0.0482)$. Difference in DFS of $\mathrm{T} 2$ patients was not significant between treatment modalities $(p=0.6207)$. We also analyzed the survival difference between treatment modalities according to other characteristics. There was no survival difference in each characteristic except for ER-positive patients OS of mastectomy group was significantly inferior to BCT group $(\mathrm{p}=0.0220)$.

\section{Discussion}

$\mathrm{BCT}$ has become an acceptable alternative treatment modality to mastectomy since the 1990 s in Korea. ${ }^{19)}$ In a nationwide survey of breast cancer treatment in Korea, the use of breast conserving surgery has increased from $18.7 \%$ in 1996 to $41.9 \%$ in $2004 .^{3,4)}$ In our hospital, more than half (51.2\%) of the patients received BCT, which was higher than the above nationwide survey results. There are several factors 
Table 2. Multivariate Analysis for Prognostic Factors Affecting Survival Outcomes*

\begin{tabular}{|c|c|c|c|c|}
\hline \multirow{2}{*}{ Variables } & \multicolumn{2}{|c|}{ Overall survival rate } & \multicolumn{2}{|c|}{ Disease free survival rate } \\
\hline & 10 year rate & p-value & 10 year rate & $\mathrm{p}$-value \\
\hline \multicolumn{5}{|l|}{ Treatment } \\
\hline BCT & $92.0 \%$ & & $80.5 \%$ & \\
\hline Mastectomy & $91.0 \%$ & 0.4766 & $85.0 \%$ & 0.2708 \\
\hline \multicolumn{5}{|l|}{ T-stage } \\
\hline $\mathrm{T} 1$ & $96.0 \%$ & & $84.9 \%$ & \\
\hline $\mathrm{T} 2$ & $84.1 \%$ & 0.0213 & $80.7 \%$ & 0.0164 \\
\hline \multicolumn{5}{|l|}{ LVI } \\
\hline Yes & $80.0 \%$ & & $60.1 \%$ & \\
\hline No & $93.3 \%$ & 0.1656 & $85.8 \%$ & 0.0143 \\
\hline \multicolumn{5}{|l|}{ Nuclear grade } \\
\hline Low & $98.9 \%$ & & $87.0 \%$ & \\
\hline Intermediate & $90.5 \%$ & & $81.3 \%$ & \\
\hline High & $86.4 \%$ & 0.0511 & $80.9 \%$ & 0.8968 \\
\hline \multicolumn{5}{|l|}{ Histologic grade } \\
\hline Well & $90.9 \%$ & & $86.6 \%$ & \\
\hline Moderate & $89.1 \%$ & & $81.5 \%$ & \\
\hline Poor & $88.9 \%$ & 0.7773 & $81.6 \%$ & 0.0038 \\
\hline \multicolumn{5}{|l|}{ ER } \\
\hline Positive & $94.4 \%$ & & $81.7 \%$ & \\
\hline Negative & $90.2 \%$ & 0.7615 & $82.3 \%$ & 0.4368 \\
\hline \multicolumn{5}{|l|}{ PR } \\
\hline Positive & $93.2 \%$ & & $80.4 \%$ & \\
\hline Negative & $92.1 \%$ & 0.6645 & $82.9 \%$ & 0.2484 \\
\hline
\end{tabular}

*abbreviations were previously introduced in Table 1

affecting surgical procedures in patients with early breast cancer. Several reports evaluating the geometrical difference with BCT have been published. ${ }^{20 \sim 22)}$ BCT was more commonly used in teaching hospitals, in larger hospitals and in hospitals with on-site radiation therapy. ${ }^{20)}$ Moreover, the physician-to population ratio, education and income levels, and the presence of a cancer center were significant predictors of the type of surgery used. ${ }^{21)}$ These factors in addition to the location, availability of radiation therapy and surgeon's preference might account for the higher rate of $\mathrm{BCT}$ at our hospital.

After BCS in patients with early breast cancer, the remnant breast is a common site of recurrence. The National Surgical Adjuvant Breast and Bowel Project (NSABP) B-06 trial showed a $39.2 \%$ cumulative rate of ipsilateral breast cancer recurrence after lumpectomy only. ${ }^{10)}$ Breast irradiation after lumpectomy reduced the risk of recurrence to about one-third (14.3\%). Data from the EBCTCG meta-analysis of randomized trials of BCS with or without breast irradiation showed a $19 \%$ reduction in the 5-year local recurrence risks $(7.3 \%$ versus $25.9 \%$ ), and $5.4 \%$ reduction in the 15 -year breast cancer mortality risk $(30.5 \%$ versus $35.9 \%) .{ }^{11)}$ The reduction rate of local recurrence in BCS with adjuvant breast irradiation was $69 \%$ compared with BCS alone $(\mathrm{p}<0.00001)$, and the reduction of breast cancer mortality was about one-sixth $(\mathrm{p}=0.0001)$.

Several randomized trials demonstrated that survival with BCS plus irradiation is equivalent to that with mastectomy. The Milan I trial randomized 701 breast cancer patients with a tumor of no more than $2 \mathrm{~cm}$ in diameter. ${ }^{15)}$ Their cumulative incidence of local recurrence was $8.8 \%$ in the BCT group and $2.3 \%$ in mastectomy group $(\mathrm{p}<0.001)$. However, the rate of death from breast cancer was $24.3 \%$ and $26.1 \%$, respectively $(p=0.8)$. The EBCTCG meta-analysis of nine trials of mastectomy versus BCS plus radiotherapy showed no apparent difference in total mortality $(22.9 \%$ vs. $22.9 \%){ }^{23)}$ In our retrospective review, the local recurrence rate of patients with pathologic T1-2N0 was $3.8 \%$ and $2.1 \%$ in the BCT and 
Table 3. Comparison of Survival Difference between Treatment Modalities according to Patients' Characteristics*

\begin{tabular}{|c|c|c|c|c|c|c|}
\hline \multirow{2}{*}{ Characteristics } & \multicolumn{3}{|c|}{$10 \mathrm{Y}$ overall survival rate } & \multicolumn{3}{|c|}{$10 \mathrm{Y}$ disease free survival rate } \\
\hline & $\mathrm{BCT}(\%)$ & Mastectomy (\%) & p-value & $\mathrm{BCT}(\%)$ & Mastectomy (\%) & $\mathrm{p}$-value \\
\hline \multicolumn{7}{|l|}{ T-stage } \\
\hline $\mathrm{T} 1$ & 96.5 & 95.7 & 0.9075 & 80.3 & 89.6 & 0.0482 \\
\hline $\mathrm{T} 2$ & 78.6 & 86.2 & 0.6210 & 81.3 & 80.2 & 0.6207 \\
\hline \multicolumn{7}{|l|}{ Multicentricity } \\
\hline Yes & 100 & 93.6 & 0.3044 & 88.5 & 79.8 & 0.9530 \\
\hline No & 91.2 & 90.7 & 0.1467 & 79.6 & 85.9 & 0.7798 \\
\hline \multicolumn{7}{|l|}{ LVI } \\
\hline Yes & 68.4 & 87.0 & 0.8096 & 61.7 & 59.6 & 0.5340 \\
\hline No & 95.7 & 91.4 & 0.1414 & 82.1 & 87.9 & 0.9965 \\
\hline \multicolumn{7}{|l|}{ EIC } \\
\hline Yes & 46.8 & 90.8 & 0.9700 & 87.4 & 81.7 & 0.9083 \\
\hline No & 95.7 & 92.0 & 0.1426 & 79.2 & 86.1 & 0.6299 \\
\hline \multicolumn{7}{|l|}{ ER } \\
\hline Positive & 97.5 & 90.7 & 0.0220 & 75.3 & 84.3 & 0.9012 \\
\hline Negative & 91.6 & 89.9 & 0.9375 & 79.2 & 84.5 & 0.7336 \\
\hline \multicolumn{7}{|l|}{ PR } \\
\hline Positive & 97.5 & 89.3 & 0.0763 & 76.4 & 81.6 & 0.5739 \\
\hline Negative & 92.7 & 91.4 & 0.4843 & 77.7 & 86.1 & 0.3619 \\
\hline \multicolumn{7}{|l|}{ Nuclear grade } \\
\hline Low & 97.8 & 100 & 0.2967 & 63.7 & 90.0 & 0.8848 \\
\hline Intermediate & 87.6 & 91.4 & 0.0785 & 75.2 & 85.3 & 0.3569 \\
\hline High & 90.4 & 84.0 & 0.5032 & 77.6 & 82.6 & 0.8536 \\
\hline \multicolumn{7}{|c|}{ Histologic grade } \\
\hline Well & 94.9 & 86.9 & 0.3442 & 94.4 & 84.4 & 0.7615 \\
\hline Moderate & 85.4 & 90.4 & 0.1269 & 73.4 & 85.4 & 0.5751 \\
\hline Poor & 93.0 & 86.1 & 0.3015 & 82.3 & 80.9 & 0.7235 \\
\hline
\end{tabular}

*abbreviations were previously introduced in Table 1

mastectomy group respectively $(\mathrm{p}=0.0810)$, the Milan I trial showed a similar tendency. Other randomized trials included patients with tumors that were larger than $2 \mathrm{~cm}$, which provided further evidence of the efficacy of BCT. ${ }^{13,14,16)}$ About four-fifths of the patients included in the EORTC 10801 trial had clinical tumor size of $2.1 \sim 5 \mathrm{~cm}$, while $48.6 \%$ of patients had pathologic tumor size of $2.1 \sim 5 \mathrm{~cm}^{14)}$ The ten-year overall survival rates were $66.1 \%$ and $65.2 \%$ in the mastectomy and BCT groups, respectively $(\mathrm{p}=0.11)$. The National Cancer Institute (NCI) randomized trial showed that $52 \%$ in the mastectomy group and $57 \%$ in the BCT group had a tumor size of $2.1 \sim 5 \mathrm{~cm}$, and their twenty-year survival rates were $58 \%$ and $54 \%$ for each group respectively $(\mathrm{p}=0.67) .{ }^{16)}$ Our study included $36.5 \%$ of patients with a tumor size larger than $2 \mathrm{~cm}$ and showed no significant difference in the OS or DFS between treatment modalities.
In Korea, there is no prospective randomized trial comparing BCT with mastectomy in early stage breast cancer. Son et al. retrospectively reviewed 3,700 patients accrued from a multi-institution study on operable breast cancer. Among them 2,821 patients $(76.2 \%)$ received a mastectomy and 860 patients $(23.2 \%)$ had BCS procedures. ${ }^{24)}$ Their cumulative incidence of locoregional recurrence at 10-years was $6.5 \%$. Although the incidence was not described according to treatment, the results were consistent with our data, $5.5 \%$ for the BCT group and $5.8 \%$ for the mastectomy group. The Korean Breast Cancer Society reported on a survival analysis of Korean breast cancer patients diagnosed between 1993 and $2002{ }^{25)}$ The five-year survival rates of stage I patients were $95.8 \%$ and $98.8 \%$ in the mastectomy and BCS group, respectively. The 5-year survival rates for stage II patients were $91.5 \%$ and $94.2 \%$ for each group, respectively. There is 
limited data comparing survival outcome between the two treatment modalities in Korea. Kim et al. reported retrospective data on 171 patients with stage I-II Breast cancer. ${ }^{26)}$ Among them, eighty-five patients received BCT. The five-year overall survival rate was $96.4 \%$ with BCT and $97.2 \%$ with mastectomy, which was not significantly different $(\mathrm{p}=0.2313)$. The five-year disease free survival rate was also not significantly different between thetwo groups $(93.4 \%$ and 95.7\%, $\mathrm{p}=0.1836$ ). Yea et al. retrospectively reviewed 62 patients with stage I-II breast cancer; 22 with BCS and 40 with mastectomy. ${ }^{27)}$ They reported a $95.5 \%$ locoregional control rate and $86.3 \%$ were satisfied with their cosmetic results in the BCT group. However, there was no report on the survival outcome. Lee et al. reported 54 patients treated with BCS followed by radiotherapy. ${ }^{28)}$ In this study, overall survival and disease free survival rates at 10 -years was $92.4 \%$ and $81 \%$, respectively. The incidence of local recurrence was $7.5 \%$, which was similar to our results. However, these reports have only a small number of patients.

This study was limited due to its retrospective analysis, short follow-up period, and heterogenous patient's characteristics. The mastectomy group had more patients with T2 stage, multicentricity, EIC, ER/PR negativity. But among these different factors between treatment groups, only $\mathrm{T}$-stage significantly affected survival outcome on multivariate analysis. Other significant prognostic factors such as LVI and histologic grade were not different from each treatment group. When we analyzed the survival outcome according to treatment modalities in same T-stage, OS was not significantly affected by treatment modalities $(\mathrm{p}=0.9075$ in $\mathrm{T} 1$ patients and 0.6210 in T2 patients). But DFS of BCT group was significantly inferior to that of mastectomy group in $\mathrm{T} 1$ patients $(\mathrm{p}=0.0482)$. This difference may be due to the tendency ofmore local recurrence in BCT group. Difference in DFS of T2 patients was not significant between treatment modalities $(p=0.6207)$. We also analyzed the survival difference between treatment modalities according to other characteristics. There was no survival difference in each characteristicexcept for ER-positive patients OS of mastectomy group was significantly inferior to BCT group ( $\mathrm{p}=0.0220$, Table 3 ).

In conclusion, our study showed a similar survival rate between BCT and mastectomy while tendency of more local recurrence in BCT group for early breast cancer. Although this study had some limitations, we suggest that BCT can be a feasible alternative to mastectomy in patients with pathologic T1-2N0 breast cancer.

\section{References}

1. Annual report of the central cancer registry in Korea (2001 2002). Ministry of Health and Welfare. Republic of Korea 2005

2. Cancer Incidence in Korea 1999-2001. Ministry of Health and Welfare. Republic of Korea 2005

3. The Korean Breast Cancer Society. Nationwide Korean breast cancer data of 2004. J Korean Breast Cancer Soc 2006;9:151-161

4. The Korean Breast Cancer Study Group. Korean breast cancer data of 1996. J Korean Surg Soc 1998;55:621-635.

5. Halsted W. The results of operations for the cure of cancer of the breast performed at the Johns Hopkins Hospital from June, 1889 to January, 1894. Johns Hopkins Hosp Bull 1894;4:297

6. Peters MV. Wedge resection with or without radiation in early breast cancer. Int J Radiat Oncol Biol Phys 1977;2:1151-1156

7. Calle R, Vilcoq JR, Zafrani B, Vielh P, Fourquet A. Local control and survival of breast cancer treated by limited surgery followed by irradiation. Int $\mathrm{J}$ Radiat Oncol Biol Phys 1986;12:873-878

8. Rissanen PM. A comparison of conservative and radical surgery combined with radiotherapy in the treatment of stage I carcinoma of the breast. Br J Radiol 1969;42:423-426

9. Mustakallio S. Conservative treatment of breast carcinomareview of 25 years follow up. Clin Radiol 1972;23:110-116

10. Fisher B, Anderson S, Bryant J, et al. Twenty-year follow-up of a randomized trial comparing total mastectomy, lumpectomy, and lumpectomy plus irradiation for the treatment of invasive breast cancer. N Engl J Med 2002;347:1233-1241

11. Clarke M, Collins R, Darby $S$, et al. Effects of radiotherapy and of differences in the extent of surgery for early breast cancer on local recurrence and 15-year survival: an overview of the randomised trials. Lancet 2005;366:2087-2106

12. Sarrazin D, Le MG, Arriagada R, et al. Ten-year results of a randomized trial comparing a conservative treatment to mastectomy in early breast cancer. Radiother Oncol 1989;14: 177-184

13. Blichert-Toft M, Rose C, Andersen JA, et al. Danish randomized trial comparing breast conservation therapy with mastectomy: six years of life-table analysis. Danish Breast Cancer Cooperative Group. J Natl Cancer Inst Monogr 1992;11: $19-25$

14. van Dongen JA, Voogd AC, Fentiman IS, et al. Long-term results of a randomized trial comparing breastconserving therapy with mastectomy: European Organization for Research and Treatment of Cancer 10801 trial. J Natl Cancer Inst 2000;92:1143-1150 
15. Veronesi U, Cascinelli N, Mariani L, et al. Twenty-year follow-up of a randomized study comparing breast-conserving surgery with radical mastectomy for early breast cancer. $N$ Engl J Med 2002;347:1227-1232

16. Poggi MM, Danforth DN, Sciuto LC, et al. Eighteen-year results in the treatment of early breast carcinoma with mastectomy versus breast conservation therapy: the National Cancer Institute Randomized Trial. Cancer 2003;98:697-702

17. Lazovich D, Solomon CC, Thomas DB, Moe RE, White E. Breast conservation therapy in the United States following the 1990 National Institutes of Health Consensus Development Conference on the treatment of patients with early stage invasive breast carcinoma. Cancer 1999;86:628-637

18. Kelemen JJ 3rd, Poulton T, Swartz MT, Jatoi I. Surgical treatment of early-stage breast cancer in the Department of Defense Healthcare System. J Am Coll Surg 2001;192:293-297

19. Lee HD, Suh CO, Jung WH, et al. Partial mastectomy with axillary lymph node dissection and radiotherapy as a new treatment modality of breast cancer ( I ). Yonsei Med J 1992;33:272-276

20. Nattinger AB, Gottlieb MS, Veum J, Yahnke D, Goodwin JS. Geographic variation in the use of breastconserving treatment for breast cancer. N Engl J Med 1992;326: 1102-1107

21. Samet JM, Hunt WC, Farrow DC. Determinants of receiving breast-conserving surgery. The Surveillance, Epidemiology, and End Results Program, 1983-1986. Cancer 1994;73:2344-2351
22. Guadagnoli E, Weeks JC, Shapiro CL, Gurwitz JH, Borbas C, Soumerai SB. Use of breast-conserving surgery for treatment of stage I and stage || breast cancer. J Clin Oncol 1998;16:101-106

23. Effects of radiotherapy and surgery in early breast cancer. An overview of the randomized trials. Early Breast Cancer Trialists' Collaborative Group. N Engl J Med 1995;333:1444-1455

24. Son BH, Ahn SH, Kwak BS, et al. The recurrence rate, risk factors and recurrence patterns after surgery in 3700 patients with operable breast cancer. J Korean Breast Cancer 2006;9:134-144

25. Society TKBC. Survival analysis of Korean breast cancer patients diagnosed between 1993 and 2002 in Korea - A Nationwide Study of the Cancer Registry. J Korean Breast Cancer 2006:9:214-229

26. Kim YS, Yoon SC, Chung SM, Ryu MR, Jung SS, Choi IB. Breast conservation therapy versus mastectomy preliminary results of pattern of failure and survival rate in early breast cancer. J Korean Soc Ther Radiol Oncol 2004;22: 115-123

27. Yea BK, Bae YT, Sim MS, Moon SE. Clinical analysis of patients with early-stage breast cancer treated by breast-preserving surgery or modified radical mastectomy. J Korean Surg Soc 1998:54:323-333

28. Lee MZ, Chun HC. Radiation therapy for operable breast cancer after conservative surgery. J Korean Soc Ther Radiol Oncol 2002;20:309-315

\title{
국문초록
}

\section{조기 유방암에서 유방보존치료와 유방절제술 치료성적 비교}

\author{
성균관대학교 의과대학 방사선종양학교실*, 외과학교실 ${ }^{\dagger}$, 혈액종양내과학교실 ${ }^{\ddagger}$

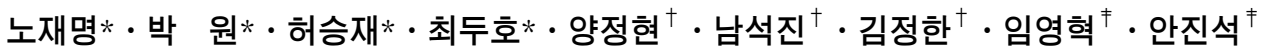

목 적: 조기 유방암에서 유방보존치료와 유방절제술의 치료 성적을 비교하고, 예후 인자를 알아보고자 하였다.

대상 및 방법: 1994년 9월부터 2002년 12월까지 본원에서 근치적 수술을 받은 병리학적 병기 T1 2NO 유방암 환자 1,200 명을 후향적으로 분석하여 유방보존치료와 유방절제술을 사이의 차이를 비교해 보았다.

결 과: 분석에 포함된 1,174 명의 환자 중 601 명이(51.2\%) 유방보존치료를 받았고 573 명이(48.8\%) 유방절제술을 받았 다. 유방절제술을 받은 군에서 유의하게 종양의 크기가 컸고, 다발성(multicentricity), 에스트로겐 및 프로게스테론 수 용체 음성 등의 인자가 더 많은 경향을 보였다. 유방보존치료 및 유방절제술을 받은 환자의 10년 생존율은 각각 $91.96 \%$ 와 $91.01 \%$ 였고 $(\mathrm{p}=0.1274), 10$ 년 무병생존율은 각각 $80.48 \%$ 와 $84.95 \%(\mathrm{p}=0.8795)$ 로 유의한 차이를 보이지 않았다

결 론: 조기 유방암에서 유방보존치료 내지는 유방절제술을 받은 군 사이에 환자 특성의 차이는 일부 있었으나 생존율 에서 유의한 차이를 보이지 않았다.

핵심용어: 유방암, 유방보존치료, 유방절제술 